\title{
Rashtriya Swayamsewak Sangh (RSS): \\ History, Ideology and its Influences on Indian Policy towards Pakistan
}

A Monograph

By

\begin{abstract}
MAJ Ghulam Murshid
Pakistan Army
\end{abstract}

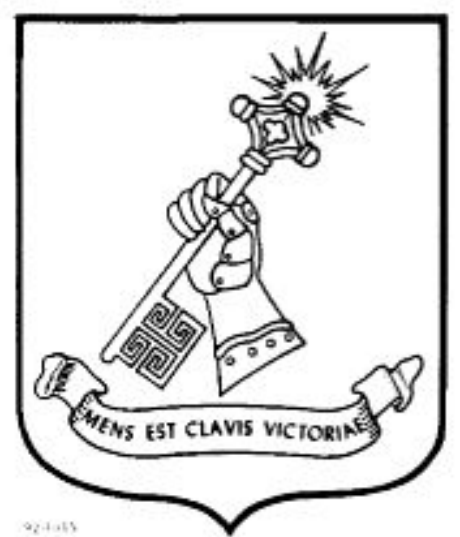

School of Advanced Military Studies

United States Army Command and General Staff College

Fort Leavenworth, Kansas

2015-01

Approved for public release; distribution is unlimited. 


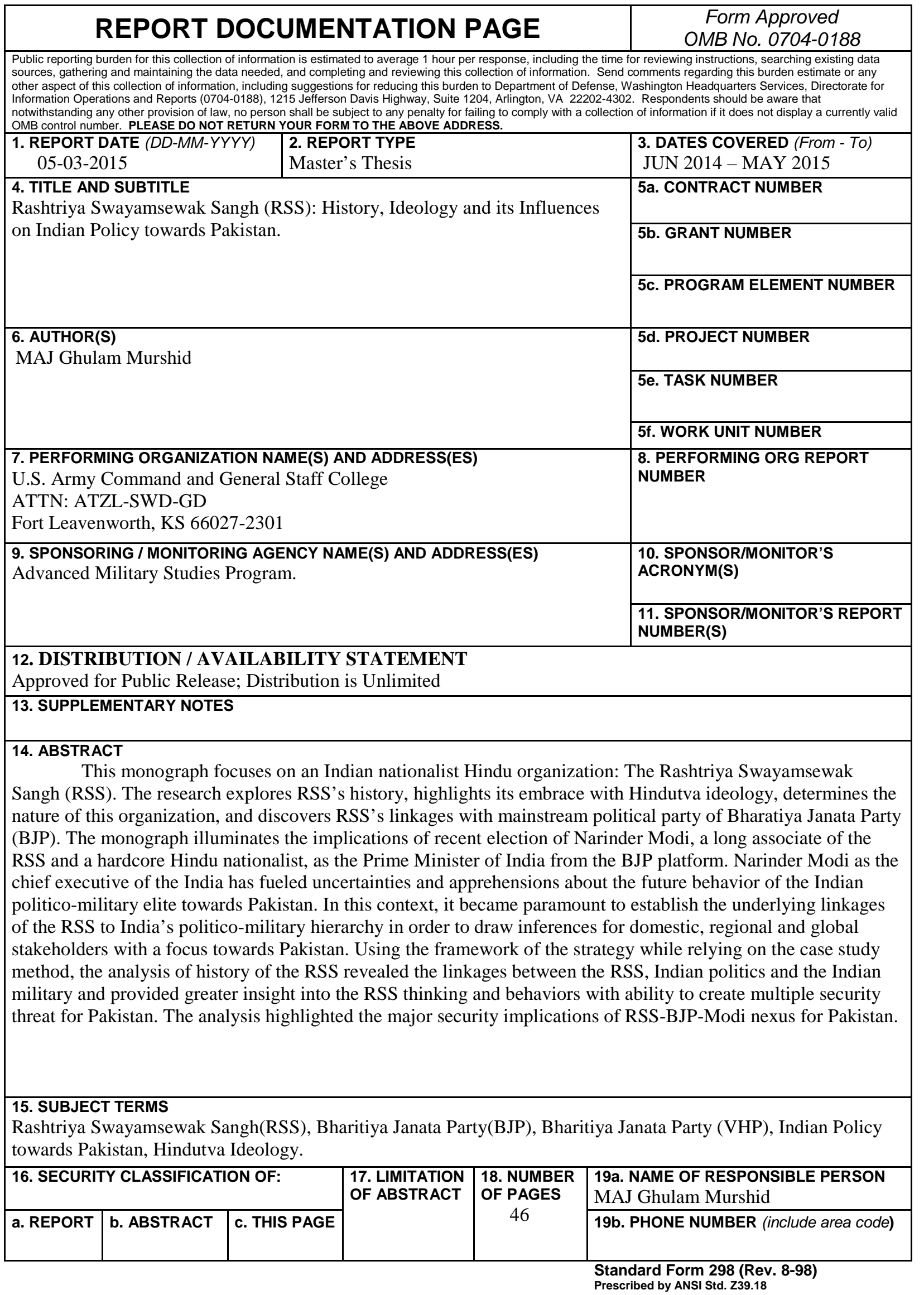




\section{Monograph Approval Page}

Name of Candidate: MAJ Ghulam Murshid

Monograph Title: Rashtriya Swayamsewak Sangh (RSS): History, Ideology and its Influences on Indian Policy towards Pakistan.

Approved by:

, Monograph Director

Bruce, Stanley, $\mathrm{PhD}$

, Seminar Leader

Craig, Berryman, COL

, Director, School of Advance Military Studies

Henry A. Arnold III, COL

Accepted this 23rd day of May 2015 by:

, Director, Graduate Degree Programs

Robert F. Baumann, PhD

The opinions and conclusions expressed herein are those of the student author and do not necessarily represent the views of the US Army Command and General Staff College or any other governmental agency. (References to this study should include the foregoing statement.) 


\begin{abstract}
Monograph Title: Rashtriya Swayamsewak Sangh (RSS): History, Ideology and its Influences on Indian Policy towards Pakistan, by MAJ Ghulam Murshid, 51 pages.

This monograph focuses on an Indian nationalist Hindu organization: The Rashtriya Swayamsewak Sangh (RSS). The research explores RSS's history, highlights its embrace with Hindutva ideology, determines the nature of this organization, and discovers RSS's linkages with mainstream political party of Bharatiya Janata Party (BJP). The monograph illuminates the implications of recent election of Narinder Modi, a long associate of the RSS and a hardcore Hindu nationalist, as the Prime Minister of India from the BJP platform. Narinder Modi as the chief executive of the India has fueled uncertainties and apprehensions about the future behavior of the Indian politico-military elite towards Pakistan. In this context, it became paramount to establish the underlying linkages of the RSS to India's politico-military hierarchy in order to draw inferences for domestic, regional and global stakeholders with a focus towards Pakistan. Using the framework of the strategy while relying on the case study method, the analysis of history of the RSS revealed the linkages between the RSS, Indian politics and the Indian military and provided greater insight into the RSS thinking and behaviors and its ability to shape multiple security threats for Pakistan. The analysis highlighted the major security implications of RSSBJP-Modi nexus for Pakistan.
\end{abstract}




\section{Contents}

Abstract ........................................................................

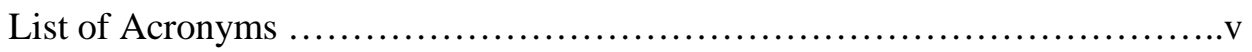

Introduction $\quad$.............................................................1

Literature Review ......................................................6

Research Methodology..............................................13

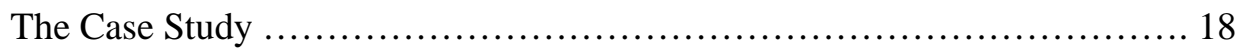

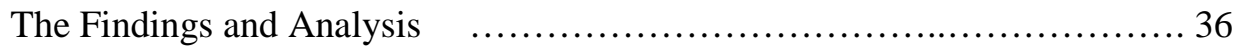

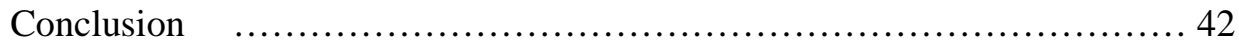

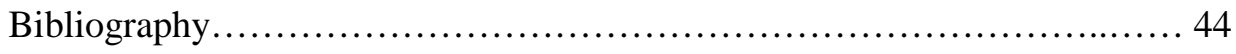




\section{Acronyms}

RSS Rashtriya Swayamsewak Sangh

BJP Bharitiya Janata Party

VHP Vishwa Hindu Parishad

BJS Bharatiya Jana Sangh 


\section{Introduction}

India happens to be the largest democracy in the World and an aspiring economic giant. The Bharitiya Janata Party (BJP) - a hardline Hindu Nationalist party - recently won the elections in May 2014 for the Indian Lok Sabha (Indian Parliament) with a simple majority. ${ }^{1}$ Narinder Modi was subsequently elected as the prime minister of India. ${ }^{2}$ Modi, and the cabinet chosen by him, have had a long association with a controversial fundamentalist organization; the Rashtriya Swayamsewak Sangh (RSS). ${ }^{3}$ The RSS has evolved from a National Volunteer Organization in 1925 to a Hindu nationalist organization of present day India. ${ }^{4}$ This organization has remained a focal point for critics - local and foreign - due to its role in extremist activities, ideology, motives, and influences on politics. ${ }^{5}$ The RSS was banned twice in India owing to these controversies. ${ }^{6}$ Modi’s recent rise to the premiership of India has, once again, brought the RSS to the forefront of discussion due to his long and controversial association with this organization. ${ }^{7}$ Narinder Modi as the chief executive of India has fueled additional uncertainties and apprehensions about the future behavior of the Indian politico-military elite. In this context, it becomes paramount to establish the underlying linkages of the RSS to India's politico-military

${ }^{1}$ Gowen, Annie, 2014. “Hindu Nationalist Sworn Narinder Modi in as India’s Prime Minister .26 May 2014. The Washington Post, http://www.washingtonpost.com/world/hindu-nationalist-narendramodi-sworn-in-as-indias-prime-minister/2014/05/26/d6f9ba54-25a6-48ac-9693932132416cf6_story.html. Accessed 2 August 2014.

${ }^{2}$ Ibid.

${ }^{3}$ Nagi, Saroj 2014. Cabinet Reshuffle: A Sarkar, by and for Modi, bound together by the RSS. First Post. November 9, 2014. http://www.firstpost.com/politics/cabinet-reshuffle-sarkar-modibound-together-rss-1794869.html. Accessed 15 November, 2014.

${ }^{4}$ Christophe Jaffrelot, The Hindu Nationalist Movement and Indian Politics (New Delhi: Penguin Books, 1996).

${ }^{5}$ Ibid.

${ }^{6}$ Ibid.

${ }^{7}$ Gopal, Priyamvada .2014. "Narinder Modi is the face of Hindu Extremism”.The Gulf News, 14 April, 2014. http://gulfnews.com/opinions/columnists/narendra-modi-is-the-face-of-hindu-extremism1.1319340. Accessed 5 August, 2014. 
hierarchy in order to draw inferences for domestic, regional and global stake holders with a focus towards Pakistan.

The RSS surfaced as a national volunteer movement in British India. However, its peculiar history has been in association with the Hindutva ideology and its role in Indian politics has always been suspected by domestic as well as international critics. The recent rise of the BJP under Narinder Modi magnifies such apprehensions because an extremist RSS is likely to be afforded more living space by the BJP. If the RSS is an extremist organization and has close linkages with the political and the military elite of India, there is a potential to not only radicalize Indian Society but to also radically influence India's policy making and military strategy towards Pakistan.

The purpose of this study is to explore the history of the RSS and determine its ideological base. The analysis of history of the RSS may reveal the linkages between the RSS, Indian politics and the Indian military. Identifying these linkages, both direct and indirect, to Indian politics and the Indian military may provide greater insight into the RSS thinking and behaviors. The analysis will focus on the influences which the RSS can have on Indian policy making and military strategy. Finally, the analysis will highlight the major security implications of this nexus for Pakistan.

The study is significant as no worthwhile academic work exists on the subject from Pakistan's perspective. First, the research provides some valuable insights into the RSS. Second, the study unveils the underlying relationship with the Indian society and the associated linkages with the politico-military elite. Besides being relevant in the Indo-Pakistan and South Asian regional context, this research will also serve as a knowledge base for future research on the subject.

To provide clarity to the reader, this research relies on three key definitions. These concepts will standardize certain terms. The definitions will also provide a basic knowledge and context to the readers. The three definitions of interest are following: Rashtriya Swayamsewak Sangh (RSS), Bharitiya Janata Party (BJP), and Hindutva Ideology. The first key definition is the RSS which is a hardline Hindu 
nationalist Indian organization. ${ }^{8}$ This organization started as a national volunteer service in $1925 .^{9}$ Though a non-political entity at its inception, RSS soon developed linkages with Indian politics. At present, RSS has strong linkages with the BJP of India. ${ }^{10}$ RSS also enjoys massive support among the predominantly Hindu population of India due to its embrace of Hindutva ideology and its anti-Muslim stance. The second key definition is the BJP, which is the present ruling part in India. BJP was established in 1980 as the political wing of the RSS. The BJP won Indian National elections in May 2014 with overwhelming majority after relying on the Hindutva ideology of the RSS. ${ }^{11}$ The third key definition is the Hindutva Ideology. This ideology is derived from Hindu religious scripture and envisions the unity of the sub-continent of India as a single entity under the Hindu rule. ${ }^{12}$ Vinayak Damodar Savarkar conceived the Hindutva ideology and he served to establish the ideological foundation necessary for the creation of the RSS. ${ }^{13}$ This ideology advocates the supremacy of the Hindu religion over other religions and envisions India to be a Hindu only state.

The main theoretical framework for this research is strategy. In Merriam Webster's dictionary, strategy is defined as the science and art of employing the political, economic, psychological, and military forces of a nation or group of nations to afford the maximum support to adopted policies in peace or war. ${ }^{14}$ Everett Dolman, in his book Pure Strategy defines strategy as "a process by which all means

${ }^{8}$ A hardline Hindu nationalist organization believes in supremacy of Hindu religion and race over other religions. It tends to build the society on the hardcore Hindutva principles.

${ }^{9}$ Christophe Jaffrelot, The Hindu Nationalist Movement and Indian Politics (New Delhi: Penguin Books, 1996), 25-50.

${ }^{10}$ Ibid.

${ }^{11}$ Ibid.

${ }^{12}$ Ibid.

${ }^{13}$ Christophe Jaffrelot, The Hindu Nationalist Movement and Indian Politics (New Delhi: Penguin Books, 1996), 25-50.

${ }^{14}$ Definition of Strategy. Merriam -Webster Dictionary. http://www.merriamwebster.com/dictionary/strategy. Accessed on 6 August, 2014. 
available to the state are considered in pursuit of a continuing political influence.” ${ }^{15}$ He also mentions that continuation of a position of advantage is the goal of strategy and not culmination. ${ }^{16}$ The constructs of policy, strategic and political aims, and strategic objectives will explain the research within this framework. Research will also use the parameters of military strategy, military aims and military objectives.

Two hypothesis are tested to determine if this study's thesis is supported. The first hypothesis is that with the Hindu nationalist ideology of the Akhand-Bharat, the RSS will incite nationalistic fervor in India. The RSS with close links to the BJP under Prime Minister Narinder Modi will indirectly impact the domestic, regional and global politics of India. The second hypothesis is that the RSS, with strong linkages to the Indian Military and Government, is likely to influence India’s policy and military strategy while shaping future security threats for Pakistan.

This study relies on six research questions to gather the empirical data to test the hypothesis. The first question is what is the source of the RSS ideology? The second question is how did the RSS evolve as an influential Hindu extremist organization? The third question is what is the structural organization of RSS is and how it is linked to ruling party (BJP) in India? The fourth question is how will the RSS, strongly linked with BJP under Narinder Modi, impact Indian policy towards Pakistan? The fifth question asks if the RSS is linked to the Indian Military? The sixth question is can the RSS impact Indian military strategy?

During the course of the research, certain limitations were confronted. The first limitation was the lack of availability of primary sources on the RSS. Limited access to primary RSS resources made it difficult to collect comprehensive and complete evidence to test the hypotheses. The evidence utilized was collected from secondary sources. The second limitation was the contemporary nature of the research

${ }^{15}$ Dolman, Everett. Pure Strategy. The university of Chicago press, 2013, 26.

${ }^{16}$ Ibid. 
subject. Research mostly relied on contemporary papers, articles, current events for data collection and analysis.

Some de-limitations are imposed for this research. The first de-limitation is to keep the research focused on a specific time period. The time period selected ranged from the creation of the RSS in 1925 until December 2014, when the BJP vowed to win the Kashmir elections in order to change the political status of Kashmir. ${ }^{17}$ The second de-limitation is to keep the research concentrated on the influence of the RSS on Indian politics and military strategy. The third de-limitation is to confine the research to IndiaPakistan context. Utilizing these de-limitations, the intent is to remain focused on the influences of the RSS on Indian policy towards Pakistan.

Several assumptions are made during the research. The first assumption is that the RSS will continue to find a living space in India as a fundamentalist Hindu organization. The second assumption is that the Indian Government under Narinder Modi will continue to maintain its intimate relationship with the RSS. The third assumption is that the peace process between India and Pakistan remains in a stalemate and stagnant posture for the near future.

This research will be presented in six sections. Section I is the 'Introduction' which includes the background of the study, statement of the problem, significance of the study, definitions of terms, theoretical framework, hypothesis and research questions, limitations, de-limitations and organization of the study. Section II presents a review of the literature. Section III will cover the methodology used for the research. Section IV will be encompass the case study in order to present the evidence. Section V will present the findings of the research and analysis. Section VI will be used to conclude the study.

${ }^{17}$ Mahmud, Tariq, 2015.The BJP’s Mission Kashmir. Tribune January 13, 2015. Accessed 20 Janaury 2015 on http://tribune.com.pk/story/820771/the-bjps-mission-kashmir. 


\section{Literature Review}

The rise of Narinder Modi as premier of India is a recent development. Moreover, no major research work existed on the subject of RSS on Indian policy making, particularly with regards to Pakistan. The availability or lack of primary resources remained a major constraint during the course of this research being an emergent event. Hence, only a few primary sources formed the basis of this research. These primary resources are used to better understand the Hindutva ideology, the genesis and evolution of the RSS and its linkages with BJP. These sources, however, were less useful in assisting to understand the influences of the RSS on Indian Policy making and its military strategy. Research relied on secondary resources such as articles, newspapers and recent events. To fill in short falls of the existing literature, certain inferences will be made during the course of the research.

The main theoretical framework for this research is strategy. Merriam Webster Dictionary defines strategy as the science and art of employing the political, economic, psychological, and military forces of a nation or group of nations to afford the maximum support to adopted policies in peace or war. ${ }^{18}$ Dolman in his book Pure Strategy defines strategy as "a process by which all means available to the state are considered in pursuit of a continuing political influence.” ${ }^{19}$ He also mentions that continuation of a position of advantage is the goal of strategy and not culmination. ${ }^{20}$ The research is explained within this framework through the constructs of policy, strategic/political aims, and strategic objectives. Additionally the parameters of military strategy, military aims, and military objectives are used to examine the RSS national strategic aims. According to Eugene Bardach, "Policy analysis is more art than science. It draws on intuition as much as method.”21 The reason for this conclusion about policy analysis is that the

${ }^{18}$ Definition of Strategy. http://www.merriam-webster.com/dictionary/strategy. Accessed on 6 August, 2014.

${ }^{19}$ Dolman, Everett. Pure Strategy. The university of Chicago press, 2013, 26.

${ }^{20}$ Ibid.

${ }^{21}$ Bardach, Eugene A Practical Guide for Policy Analysis: The Eightfold Path to More Effective Problem Solving. 2nd ed. (Washington, D.C: CQ Press, 2005), xiv. 
complexity of the research area combined with the involvement of intricate human entities and the uncertainty of their behavior creates additional uncertainty. Moreover, Michael White argues that “Policies, and public problems in general, are embedded in complex, dimly perceived institutional and historical context. Stakeholders are numerous, and their interests are not obvious. Any given situation will have meanings to some that can hardly be imagined by others of different background, training, or social location.”22 Immediately following the identification of the problem set there is always a need to explore the relevant factors involved in the problem situation. This process can assist in mitigating the complexity of the problem situation and to expose the underlying facts and interests. White states that the relevant factors are the institutional context, the historical context, and key players along with their interests. ${ }^{23}$

This research is based on a number of key ideas. These ideas will serve as defined parameters for this research and provide the basis for the data collection. Additionally these ideas will also help draw the inferences in order to structure the analysis. At the end, the same concepts will facilitate reaching the conclusions.

The first key concept is that ideology can play a vital role in modern day politics. In India, the Hindutva ideology plays a significant role in modern Indian politics. ${ }^{24}$ Though secular in nature, India remains as the largest and only major Hindu country in the world. The Hindutva Ideology, due to its close linkage to the Hindu religion, can be used to stimulate Hindu nationalism amongst a massive Hindu Indian population. This ideology, when stimulated or implemented in the current Indian socio-political context, challenges present ground realities and creates additional tension amongst multi-religious society of India. A hyper Hindu-nationalist India incurs concern for the religious minorities in India.

\footnotetext{
${ }^{22}$ White, Michael J., “Policy Analysis Models,” Encyclopedia of Policy Studies, edited by Stuart S. Nagel (New York: Marcel Dekker Inc., 1983), 44.

${ }^{23}$ Ibid.

${ }^{24}$ Hindutva: The Great Nationalist Ideology. The Official BJP Site, http://www.bjp.org/index.php?option=com_content\&view=article\&id=369:hindutva-the-great-nationalistideology\&Itemid=501. Accessed 25 July 2014.
} 
The second key concept of the research signifies the role of ideological organizations in shaping the perceptions of a particular society which links the individuals of a society in a common cause and purpose. The subject of the research is the RSS as an ideological organization. The RSS, being part of the greater ‘Sangh Parevar', remains the major source for stimulating Hindu ultra-nationalist sentiments in Indian society, which is by and large secular in nature. ${ }^{25}$ Since its inception, the RSS is viewed skeptically due to its linkage with extreme Hinduvta ideology, anti-minority stance and role in Indian politics. The RSS not only causes concerns for the minority groups in India by threatening their survival, but also portrays a different view of Indian history, influencing Indian population’s view of their history.

The third key idea focuses on the intimate relationship between ideological organizations and mainstream political parties in modern day politics. ${ }^{26}$ The research focuses on the linkage between the RSS and the Indian mainstream politics. The BJP, as the political wing, maintains a very close relationship with the RSS. ${ }^{27}$ The BJP has historically maintained an RSS inspired Hindu ultra-nationalist stance. It not only maintains an organizational level linkage with the RSS, but individual ties between the BJP leadership and the RSS are even stronger. The rise of Narinder Modi, on the BJP platform with the RSS inspired political manifesto, is a case in point. Hence, this RSS-BJP nexus requires a thorough examination to understand the implications.

The fourth concept highlights that the ideological organizations, closely linked with mainstream political parties in power, can influence national strategy as well as domestic and foreign policy making

25 'Sangh Parivar' is family of dozens of Hindu Nationalist organizations which tend to work in close harmony and coordination to implement Hindutva Ideology in India.

${ }^{26}$ Busch, Carsten. "The Policy of the Bharatiya Janata Party, 1980 and 2008: Possible Influence of Hindu Nationalism on Indian Politics” (master's thesis, US Naval Post Graduate College, 2009), accessed August 4, 2014, http://calhoun.nps.edu/handle/10945/4765.

${ }^{27}$ Mehta, Mandavi. “The Role of Hindutva in Indian Politics”. The South Asia Monitor, no.55, (February 2003). Accessed 5 August, 2014. http://www.ciaonet.org/pbei/csis/sam/sam55/. 
of a nation. ${ }^{28}$ The RSS, linked closely with the BJP under Mr. Narinder Modi, can not only shape the domestic policy but can also influence India’s foreign policy. The RSS, owing to its anti-Muslim stance, is fully capable of shaping India's policy towards Pakistan. A deliberate policy shift at national level may result in a change in the Indian military strategy against Pakistan in near future. The BJP has been giving away its major cabinet positions to RSS members and it becomes paramount to explore the underlying interests of the present Indian government towards Pakistan. ${ }^{29}$ This concept will also help draw pertinent inferences from Pakistan’s perspective.

Currently, there is no major research work available on the specific subject of the RSS and its influences on Indian policy towards Pakistan. However, there is important academic work available which explores the basis of the Hinduvta ideology, the genesis of the RSS, its linkages with the BJP over a significant period of time, and the influences of the RSS on the Indian policy making. This literature is sufficiently available to enable understanding of the Hindutva ideology, the organization of the RSS and its association with the Indian politics through the BJP. To effectively study the recent rise of Hindu nationalist leadership, however, the literature relies on research of day-to-day journal articles, newspapers and current events.

In “The Policy of the Bharatiya Janata Party, 1980 and 2008: Possible Influence of Hindu Nationalism on Indian Politics”, Busch describes the nature of the BJP politics. He informs us how the BJP used Hindu nationalist ideology for political gains. His research also illuminates the close linkages between the BJP and the Hindu nationalist organizations like the RSS. He argues that "although the BJP

\footnotetext{
${ }^{28}$ Busch, Carsten. "The Policy of the Bharatiya Janata Party, 1980 and 2008: Possible Influence of Hindu Nationalism on Indian Politics” (master's thesis, US Naval Post Graduate College, 2009), accessed August 4, 2014, http://calhoun.nps.edu/handle/10945/4765.

${ }^{29}$ Nagi, Saroj 2014. Cabinet Reshuffle: A Sarkar, by and for Modi, bound together by the RSS. First Post. November 9, 2014. http://www.firstpost.com/politics/cabinet-reshuffle-sarkar-modibound-together-rss-1794869.html. Accessed 15 November, 2014.
} 
shelved the Hindu nationalist objectives from 1980-2008, it is still a nationalist party and is capable of reviving its Hindu nationalist objectives if it can gain advantages by doing so". ${ }^{30}$

Mandavi Mehta, in her article “The Role of Hindutva in Indian Politics”, mentions the intimate relationship between the BJP politics and the RSS ideology. She argues that the growth of Hindutva politics by the BJP cannot be separated from the grassroots social movement. The BJP belongs to a family of organizations known as the Sangh Parivar or "Sangh Family", which collectively represent the ideology of Hindutva. The Rashtriya Swayamsevak Sangh (RSS) provides the organizational backbone of the Hindutva movement and has a paramilitary nature. ${ }^{31}$

K.K.Pathak, in his analysis “Of Jaswant Singh, the BJP and the RSS”, elaborately explores the genesis of the RSS as social movement and then tracks its transition into an ultra-nationalist organization. ${ }^{32}$ He also defines how the RSS was able to bring its ideology into mainstream Indian politics through the establishment of the BJP in $1980 .{ }^{33}$ He argues, "In my considered opinion RSS is no longer a social organization. It has become more political and less social over the past three decades or so. Its political teeth are hardly helpful in BJP becoming a national party in the true sense”. ${ }^{34}$ It is not representative of all sections of our society. The more so as the Muslim community is hardly friendly to BJP because of its links with RSS and Vishwa Hindu Parishad (VHP).”35

${ }^{30}$ Busch, Carsten. "The Policy of the Bharatiya Janata Party, 1980 and 2008: Possible Influence of Hindu Nationalism on Indian Politics” (master's thesis, US Naval Post Graduate College, 2009), accessed August 4, 2014, http://calhoun.nps.edu/handle/10945/4765.

${ }^{31}$ Mehta, Mandavi. “The Role of Hundutva in Indian Politics”. The South Asia Monitor, no.55, (February 2003). Accessed 5 August, 2014. http://www.ciaonet.org/pbei/csis/sam/sam55/.

${ }^{32}$ Pathak, K. K. Of Jaswant Singh, the BJP and the RSS. Mumbai: The Rajaji Foundation, 2010. Accessed 10 August, 2014. http://www.freedomfirst.in/freedom-first/pdf/jaswant-singh-book.pdf.

${ }^{33}$ Ibid.

${ }^{34}$ Ibid.

${ }^{35}$ Ibid. VHP is one of the Hindu Nationalist Organization as part of Sangh Parivar which operates to promote the Hindutva Ideology in India. 
Amrit Bagia, in his thesis “Understanding India’s National Security Objectives through Indian Sources” provides some insights into the way India defines its national security objectives. Bagia defines these objectives through the lens of 'Three Concentric Circles' of global, regional and immediate neighborhood. ${ }^{36}$ In the May 2014 edition of 'The Economist', one of the articles comments on the likely influences of the RSS on domestic and foreign policy of India. ${ }^{37}$ The article "India’s Hindu Nationalists: The Men in Shorts”, asserts that "If Modi becomes prime minister, members of the broad 'Sangh Parivar' family say they expect a more forceful approach to Pakistan and China. ${ }^{38}$ School textbooks could be reworked to show history 'in the right way', as one puts it, for example by telling how Maratha kings triumphed over Muslim armies.” ${ }^{39}$ In “Civil Military Relations: A Comparative Study of India and Pakistan”, Bhimaya Kotera magnifies the civil-military relations between the Indian politicians and the military hierarchy. ${ }^{40}$ Understanding this relationship in paramount for appreciating the way Indian political hierarchy dominates Indian military hierarchy while keeping the military subservient. This dissertation also helps to substantiate the argument that the RSS, through the BJP, can influence the military strategy of India due to the civil-military power structure. ${ }^{41}$

The primary sources of literature consulted for this research provides a basis to test some of the hypotheses of this study. However, it seems deficient after the recent change of power structure in Indian politics. The available literature additionally fails to highlight the underlying linkages and influences of

${ }^{36}$ Bagia, Amrit. Understanding India's National Security Objectives through Indian Sources. (master’s thesis , George Town University, 2011). Accessed 12 August, 2014. https://m.repository.library.georgetown.edu/bitstream/handle/10822/553439/bagiaAmrit.pdf?sequence=1.

${ }^{37}$ Op-ed. 2014.India’s Hindu Nationalists: The Men in Shorts”, The Economist May 2014.

${ }^{38}$ Ibid.

${ }^{39}$ Ibid.

${ }^{40}$ Kotera, Bhimaya. “Civil Military Relations: A Comparative Study of India and Pakistan”, (Dissertation for Rand Graduate School, 1997). Accessed 25 October, 2014. http://www.rand.org/content/dam/rand/pubs/rgs_dissertations/2006/RGSD136.pdf.

${ }^{41}$ Ibid. 
the RSS in shaping Indian policy in the regional strategic context especially with reference to Pakistan. Hence, to test the hypotheses, research relies on the secondary sources of literature in order to draw inferences. 


\section{Research Methodology}

The research will rely on the case study method to test the hypotheses. The time period from 1925 to 2014 will be covered to explore the history, ideology and evolutions of the RSS. The hypotheses of the research will be tested through answering the research questions in detail. While doing so, the structured, focused approach will be adopted during the research.

The Merriem-Webster’s dictionary defines a case study as “An intensive analysis of an individual unit (as a person or community) stressing developmental factors in relation to environment." ${ }^{42}$ According to this definition, case studies tend to be more detailed, complete and deep in substance. The case study also emphasizes "developmental factors” while focusing on the evolution of a particular case in time through different interrelated events. Case studies also highlight the importance of environment and provide context to the case under consideration. ${ }^{43}$

This research is based on a single case study divided in three different time periods. The study provides insights into the genesis and the evolution process of the RSS from the creation of the RSS in 1925 to the rise of Narinder Modi as prime minister of India on BJP's platform and Kashmir elections in November/ December 2014. ${ }^{44}$ The division of this case study into three time periods from 1925 (Establishment of the RSS as a national service organization) to 1947 (the independence of India), from 1947 to May 1980 (Establishment of The Bharatiya Janata Party), and from 1980 (Establishment of The Bharatiya Janata Party) to December 2014 (the Kashmir elections under BJP Government’s supervision with Narindra Modi as prime minister of India). ${ }^{45}$ This case study will provide a chance to focus on the

${ }^{42}$ Definition of the Case Study. Merriam Webster Dictionary. http://www.merriamwebster.com/dictionary/strategy. Accessed 16 August, 2014.

${ }^{43}$ Flyvbjerg, Bent, Case Study, The Sage Handbook of Qualitative Research, $4^{\text {th }}$ Edition, Thousand Oaks, CA, 301-316.

${ }^{44}$ Gowen, Annie. 2014. "Hindu Nationalist Sworn Narinder Modi in as India’s Prime Minister, 26 May 2014.The Washington Post, http://www.washingtonpost.com/world/hindu-nationalist-narendramodi-sworn-in-as-indias-prime-minister/2014/05/26/d6f9ba54-25a6-48ac-9693932132416cf6_story.html. Accessed 2 August, 2014.

${ }^{45}$ Ibid. 
“developmental factors”. It will also provide context to the research while describing the environmental relations to the "developmental factors".

This study will use the method of structured, focused comparison to analyze the case studies. George and Bennett describe this method as simple and straightforward in which the researcher writes specific and focused questions that reflect the research objective. ${ }^{46}$ The purpose of these specific questions is to standardize data collection process in order to develop and articulate the findings of the cases. The deliberate analysis of only a certain time period and specific theoretical framework of strategy, policy and military strategy focuses the method. The research objective is for the study to determine how the RSS developed as an organization and influenced Indian policy making, and military strategy in three time periods: from 1925 (Establishment of the RSS as a national service organization) to 1947 (the independence of India); from 1947 to May 1980 (Establishment of The Bharatiya Janata Party); and from 1980 (Establishment of The Bharatiya Janata Party) to December 2014 (the Kashmir elections under BJP Government's supervision with Narindra Modi as prime minister of India). ${ }^{47}$

Two hypotheses are tested to determine if this case study's thesis is supported. The first hypothesis is that, with the Hindu nationalist ideology of the Hindutva, the RSS can incite nationalistic fervor in India. The RSS, with its close links to BJP under Prime Minister Narinder Modi, will indirectly impact the domestic politics of India. The powerful influence of the RSS with mainstream Indian politics can also shape the regional and global politics of India. This hypothesis is significant because it will define and explore developmental factors in the evolution of the RSS. Testing this hypothesis is likely to assist in discovering the ideology, history, organization and functioning of the RSS. The testing will also

${ }^{46}$ Alexander L. George, Andrew Bennett. Case Studies and the Theory Development in the Social Sciences. 2005.

${ }^{47}$ Busch, Carsten. "The Policy of the Bharatiya Janata Party, 1980 and 2008: Possible Influence of Hindu Nationalism on Indian Politics” (master’s thesis, US Naval Post Graduate College, 2009). Accessed August 4, 2014. http://calhoun.nps.edu/handle/10945/4765. 
explore the causes and motives of the RSS's popular support in India and its role in mainstream politics through the BJP platform.

The second hypothesis states the RSS maintains strong linkages with Indian mainstream policy makers and military hierarchy. Through strong connections with mainstream policymakers, the RSS has the capability to influence military strategy of India. The RSS has intentions to shape India's policy and military strategy towards Pakistan based on its ideology. This factor is likely to increase the challenges of a difficult and already complex security threat environment for Pakistan. The hypothesis is important to understand the relationship between the RSS and the Indian policy formulation. The focus will be to discern the intricate relationship of the RSS with mainstream Indian politics of the BJP and its political leadership while testing this hypothesis. Effort will also be to magnify the influences of the RSS on Indian military thinking. Through analyzing the recent events, the intent is to reveal the capability of the RSS to shape India’s policy and military strategy towards Pakistan.

The study relies on six research questions to gather the empirical data to test the hypothesis. The first question is what is the source of the RSS ideology? To understand an organization, it is of paramount importance to understand the specific ideology upon which it is built. By discovering and tracing the source of its ideology, the research will define the causes and illuminate motives of the RSS's genesis. The second question is how did the RSS evolve as an influential Hindu extremist organization? Addressing this question is significant in order to discern the developmental factors related to the evolution of the RSS. While responding to this question, the focus will be on identifying the nature of the RSS transition from a volunteer service organization to a fundamentalist Hindu organization. This analysis will also help uncover the underlying political, religious and social factors which contributed in changing the nature of the RSS. The third question is what the structural organization of RSS is and how it is linked to ruling party (BJP) in India? Illuminating the established ideology and evolution of the RSS, it becomes necessary to explore the close relationship of the RSS with the BJP, which was established in 
1980 as RSS's political wing to promote its ideology. ${ }^{48}$ The discovery of this linkage enable analysis to focus on exploring the organizational structure of the RSS in Indian society. The analysis will also help disclose the RSS's methodology for garnering political support. The fourth question is how will the RSS, as an organization strongly associated with the BJP under Narinder Modi, impact Indian politics domestically, regionally and globally? Addressing this question is vital in order to unveil the ideological influences of the RSS on Narinder Modi. Exploring the nature of the long association of Narinder Modi with the RSS, who is now Prime Minister of India, will assist in drawing inferences on the possible policy goals of new Indian government. The question will assist in the estimate of the capability of the RSS to shape and influence Indian decision making process. The fifth question inquires: is the RSS linked to Indian Military? This question is vital to confirm or deny the linkage between the RSS and the Indian military hierarchy. While answering this question, the intent is to determine if there is a possible underlying relationship between the RSS and the Indian military. This question will also highlight the nature of the RSS-Indian Military relationship and the continuities or discontinuities therein. The sixth question is can the RSS influence or impact Indian military strategy towards Pakistan? Addressing this question is important to analyze and measure the volume of RSS's influences on Indian military's strategic thinking. Through an investigation of the possible influences, the possibility of shaping the Indian military strategy will be ascertained. With such possibilities illuminated, it becomes possible to determine and anticipate future challenges for Pakistan.

Due to lack of availability of primary sources during the course of the research the data was collected from the secondary sources. Data was collected from the secondary sources in the form of a few books, research papers and newspaper articles to explore the history and ideology of the RSS. Data was collected from day to day news and current events for exploring the relationship between the RSS, Indian politics and the Indian military, and its influences on Indian policy towards Pakistan,. Due to the contemporary nature of the research subject, data was collected from day to day news and current events.

\section{${ }^{48}$ Ibid.}


This research uses the case study method to test the hypothesis of the study. By adopting a structured focused approach method, the RSS and its evolution is analyzed through its history and ideology. This method is useful in identifying the interrelated developmental factors of the RSS and its influences. This also helped in framing inferences from the research and draw pertinent conclusions. 


\section{The Case Study}

The RSS is the prime focus of the case study. While studying the case, initial efforts are directed at exploring the history, organization and its ideology. The subsequent endeavor is to establish the role of the RSS in Indian politics having identified these threads. The focus will remain on underlining the direct relationship between the RSS and the individuals in Indian politics while highlighting these linkages with Indian politics. The intricate and indirect relationship between the RSS and the Indian military hierarchy will be ascertained. Finally, the RSS’s level of the influence on Indian policy and military strategy towards Pakistan will be determined.

The case study covers the time period from the creation of the RSS in 1925 to rise of Narinder Modi as prime minister of India on BJP’s platform and Kashmir elections in November/ December 2014. This time period traces the development of the RSS from its inception to its rise. The time period also helps in discerning the evolving nature of this organization while identifying transitions from its voluntary national service nature to a politically aligned force with nationalistic and fundamentalist overtones. The case is further divided into three internal cases based on particular time periods.

The first phase covers the time period from the creation of the RSS in 1925 to Indian independence in $1947 .{ }^{49}$ This phase focuses on the genesis of the RSS as an organization. During this phase, the case study traces the foundational ideology, initial motives and nature of RSS's role in the British India. This case also explores the amount of popular support enjoyed by the RSS in preindependence India. The second phase covers the time period from Indian independence in 1947 to the establishment of the BJP in $1980 .{ }^{50}$ In this phase, the case study determines the status of the RSS within an independent Indian state. It highlights RSS’s way of working in Indian society while trying to expand

${ }^{49}$ Mehta, Mandavi. "The Role of Hindutva in Indian Politics". The South Asia Monitor, no.55, (February 2003). Accessed 5 August, 2014. http://www.ciaonet.org/pbei/csis/sam/sam55/.

${ }^{50}$ Busch, Carsten. "The Policy of the Bharatiya Janata Party, 1980 and 2008: Possible Influence of Hindu Nationalism on Indian Politics” (master's thesis, US Naval Post Graduate College, 2009), accessed August 4, 2014, http://calhoun.nps.edu/handle/10945/4765. 
its organization while maintaining the popular support. The phase is also vital to stress various dynamics of the Indian government's official response towards RSS. The third phase covers the time period from the creation of the BJP in 1980 to November 2014. This phase is critical to examine the accentuation of the RSS as a politically aligned organization. This time period is also marked with a major transition in the nature of the RSS, highlighting an increase of its political clout in Indian society. This phase also sees RSS's zenith with its hardcore member rising to the premiership of India in 2014.

The first question is to determine what is the source of the RSS ideology? To understand an organization like the RSS, it is of paramount importance to understand the specific ideology upon which it is build. By discovering the source of its ideology from 1925-2014, the case will define the causes and motives of the RSS's genesis. The case study will also explore whether this ideology has remained unchanged or otherwise while answering this particular question.

With the dawn of the early $20^{\text {th }}$ century British India saw the emergence of some new ideologies and political entities on sub-continent. The RSS was one of those entities amongst the Indian National Congress (Established 1885) and the newly established the Muslim League (Established 1906). ${ }^{51}$ Evidence shows that the Hindu nationalistic ideology of Hindutva provided the basis for creation of the RSS. ${ }^{52}$ Vinayak Damodar Savarkar, who defined and elaborated the Hindutva ideology in his Essentials of Hindutva (1922), provided the ideological foundations of the RSS. ${ }^{53}$ In his book, while introducing the new concept of Hindutva, Savarkar defined three pillars of a Hindu Nation: a common holy ground, a common blood and a common culture. It is also noteworthy to mention that Buddhists, Jains and Sikhs were included in this nationalistic concepts. However, Savarkar excluded the Muslims from having any

\footnotetext{
${ }^{51}$ Bose, Anuja. "Hindutva and the Politicization of Religious Identity in India”, Journal of Peace, Conflict and Development, Issue 13, (February 2009). Accessed July 292014. www.peacestudiesjournal.org.uk1.

52 Ibid.

53 Ibid.
} 
ties to the Indian lands. ${ }^{54}$ His ideas had many parallels with the Rassenideologie of the Nazis in Germany. ${ }^{55}$ Inspired from the Hindutva ideology, Keshav Baliram Hedgewar created the RSS in 1925 with initial motives to serve as a volunteer force for the Hindus of the British India. ${ }^{56}$

Since the creation of the RSS, the Hindutva has remained the core ideology of the RSS consistently propagating the supremacy of the Hindu religion and race in India. ${ }^{57}$ This ideological thread is observed commonly in all earlier defined phases from 1925-2014. Throughout this time period, the only distinguishable phenomenon is the transition of the ownership and the use of this Hindutva ideology. ${ }^{58}$ Before the Indian independence, from 1925-1947, the Hindutva ideology was exclusively owned by RSS which was a political non-entity in phase one. In phase two, from 1947-1980, this ideology remained dormant but struggled to survive with the ownership by several communal and religious organizations to include the RSS. From 1980-2014, in phase three, this ideology saw its two climaxes. The first high point was the transition of ownership of Hindutva ideology from a non-political RSS to a strong and politically aligned RSS. ${ }^{59}$ The second pinnacle can be observed after rise of Narinder Modi as the Prime Minister of India who is one of RSS's longtime hardcore member and harbinger of

\footnotetext{
${ }^{54}$ Levy, Guenter "Militant Hindu Nationalism: The Early Phase” (research project, University of Massachusets, 1967), accessed August 10, 2014. http://www.dtic.mil/dtic/tr/fulltext/u2/654932.pdf.

${ }^{55}$ Ibid.

${ }^{56}$ Ibid.

${ }^{57}$ Hindutva: The Great Nationalist Ideology. The Official BJP Site, http://www.bjp.org/index.php?option=com_content\&view=article\&id=369:hindutva-the-great-nationalistideology\&Itemid=501. Accessed 25 July, 2014.

${ }^{58}$ Ibid.

${ }^{59}$ Busch, Carsten. "The Policy of the Bharatiya Janata Party, 1980 and 2008: Possible Influence of Hindu Nationalism on Indian Politics” (master's thesis, US Naval Post Graduate College, 2009), accessed August 4, 2014, http://calhoun.nps.edu/handle/10945/4765.
} 
Hindutva ideology. ${ }^{60}$

The second question is how did RSS become an influential Hindu extremist organization and how did it evolve? The evidence available is sufficient to support the fundamentalist and extremist nature of the RSS. From 1925 to 2014, the RSS remained a fundamentalist and militant organization with nationalistic and communal orientations. Founded in 1925 as a national service organization, the RSS quickly changed its role in response to the political efforts of the Indian National Congress. The Indian National Congress sought a political solution of the status of the sub-continent at the end of the British Raj through political means. ${ }^{61}$ The RSS aligned itself with militant forces at the time to achieve an extreme path and propagated the national narrative of the Hindu right for the whole of the British India. The strong linkages to Hindutva ideology not only aroused nationalistic fervor to undo the partition of British India but also took a communal stance, targeting Muslims of British India. ${ }^{62}$ Jyotirmaya Sharma, in his book “Terrifying Vision: M.S. Golwalkar, The RSS and India”, mentions that M.S. Golwalkar, in his mental universe defined two enemies to the Hindutva ideology: politics and the Muslims. ${ }^{63}$ This understanding and perception by the RSS leadership defined the role and nature of the RSS in days to

${ }^{60}$ Gowen, Annie.2014. “Hindu Nationalist Sworn Narinder Modi in as India’s Prime Minister”. Washington Post, May 26. Accessed August 2, 2014. http://www.washingtonpost.com/world/hindunationalist-narendra-modi-sworn-in-as- indias-prime-minister/2014/05/26/d6f9ba54-25a6-48ac-9693932132416cf6_story.html.

${ }^{61}$ Busch, Carsten. "The Policy of the Bharatiya Janata Party, 1980 and 2008: Possible Influence of Hindu Nationalism on Indian Politics” (master's thesis, US Naval Post Graduate College, 2009), accessed August 4, 2014, http://calhoun.nps.edu/handle/10945/4765.

${ }^{62}$ Levy, Guenter "Militant Hindu Nationalism: The Early Phase” (research project, University of Massachusets, 1967), accessed August 10, 2014. http://www.dtic.mil/dtic/tr/fulltext/u2/654932.pdf.

${ }^{63}$ Kulkarni, Sudheendra. Book Review on "Terrifying Vision: M.S. Golwalkar, the RSS and India”. April 2007. ), accessed August 10, 2014 .http://www.esamskriti.com/essay-chapters/Terrifyingvision-M-S-Golwalkar,-the-RSS-ad-India--1.aspx. 
come. The RSS maintained its anti-Muslim stance from 1925 till the partition of the British India and played its role in anti-Muslim riots in 1930s and during the partition days. ${ }^{64}$

The second phase, from 1947-1980, saw the rise of fundamentalism in India through a score of Hindu fundamentalist organizations similarly aligned with the RSS ideology. After the partition of the British India, in 1948, a fanatic Hindu communalist linked closely to the RSS, assassinated Mahatma Gandhi. ${ }^{65}$ This act of violence compelled the newly formed Union of India to put a ban on the RSS in 1948 which was later lifted in 1949 on the condition of its confinement to a non-political role. ${ }^{66}$ In 1950 s, the RSS propagated its Hindutva ideology with its extremist stance through the Bharatiya Jana Sangh (BJS), which was created by the RSS as a political force. The Bharatiya Jana Sangh's political agenda, apart from formation of a 'Hindu Rashtra', included the ban on cow slaughter, repeal of the Hindu Marriage Act and other Anti- Hindu laws, and a tough anti-Pakistan policy. ${ }^{67}$ Another Hindu fundamentalist organization, Vishwa Hindu Parishad (VHP), was established in 1964 to promote the Hindutva ideology while undertaking an Anti-Muslim stance. No major incidents occurred in the second phase, but the RSS in concert with the VHP and BJS pursued a nationalistic and fascist agenda during the entire time-period. From 1975-1977, the RSS was again banned due to its dubious role in Anti-Sikh riots during the Emergency period in India. ${ }^{68}$

The period from 1980-2014 observed a continuous nationalistic and fundamentalist trend by the RSS. The emergence of a militant threat can also be identified during this period. After the establishment

\footnotetext{
${ }^{64}$ Levy, Guenter "Militant Hindu Nationalism: The Early Phase” (research project, University of Massachusets, 1967), accessed August 10, 2014. http://www.dtic.mil/dtic/tr/fulltext/u2/654932.pdf.

${ }^{65}$ Ibid.

${ }^{66}$ Ibid.

${ }^{67}$ Ibid.

${ }^{68}$ Shah, Chayanika "Hindu Fundamentalism in India: Ideology, strategies and the experience of Gujrat”. Accessed August 3, 2014. http://www.tigweb.org/action-tools/projects/.../07\%20HF\%20in\%20 India.pdf.
} 
of BJP as a main political force, the RSS started increasing its influence and even undertook an extreme stance against the Muslims of India. ${ }^{69}$ The year before the formation of the government by the BJP, the Babri Mosque was demolished by Hindu extremists in December $1992 .{ }^{70}$ The continuous inaction by the government during this violent period against the Muslims was clear sign of the growing and unchallenged strength of the Hindu fundamentalists under the patronage of the RSS and other aligned organizations. ${ }^{71}$ Owing to its alleged role, the RSS was banned for the third time following the Babri Mosque incident. ${ }^{72}$ The massacre of the Muslims in the Indian State of Gujarat between February and March 2002 also serves to illuminate the success of the Hindutva project in all its dimensions through the tacit approval of state government of BJP. ${ }^{73}$ It is noteworthy to mention that Narinder Modi, a long time RSS associate, was the Chief Minister of the Gujarat State at the time. ${ }^{74}$ Now, after Narinder Modi's rise to the office of Prime Minister, the RSS is again at the fore front to establish the Hindu Rashtra.

Moreover, the suspected role of the RSS members in Samjhota Express Bombing and Malegaon Bombing also exposes the militant face of the RSS. ${ }^{75}$ One major point of the BJP’s political manifesto was the

${ }^{69}$ Ibid.

${ }^{70}$ Marty, Martin.2014. “Hindu Fundamentalism”. Huffington Post. May 19. Accessed August 5, 2014. http://www.huffingtonpost.com/martin-marty/hindu-fundamentalism _b_5352547.html .

${ }^{71}$ Ibid.

${ }^{72}$ Pathak, K. K. Of Jaswant Singh, the BJP and the RSS. Mumbai: The Rajaji Foundation, 2010. Accessed 10 August, 2014. http://www.freedomfirst.in/freedom-first/pdf/jaswant-singh-book.pdf.

${ }^{73}$ Shah, Chayanika "Hindu Fundamentalism in India: Ideology, strategies and the experience of Gujrat”. Accessed August 3, 2014. http://www.tigweb.org/action-tools/projects/.../07\%20HF\%20in\%20 India.pdf.

${ }^{74}$ Ibid.

${ }^{75}$ Gokhale, Nitin. "Lt Colonel Purohit: Did the Army sell short an effective officer?” June 2012. Accessed October 2 2014.http://www.ndtv.com/article/india/lt-colonel-purohit-did-the-army-sell-shortan-effective-officer-237995. Samjhota Expree Bombing took place in a train between Delhi (India) and Lahore (Pakistan) on 18 February 2007. 68 Pakistani nationals were killed during this terrorist action. Malegaon Bombing took place in a Muslim cemetery in Maharastra State of India on 8 September 2006.37 persons, mostly Muslims, were killed and 137 were injured in this incident. 
establishment of the Ram Temple in place of the Babri Mosque, which has been a well-established and long-time RSS religious goal. ${ }^{76}$ After the 2014 elections, the state of Gujarat has been directed to re-write the Indian history books in order to project the Hindutva ideology and further undermine the role of the Muslim rulers in the development of India. ${ }^{77}$ The present Indian government's recent successful efforts to ban the publishing of Wendy Doniger's book “The Hindus: An Alternative History,” is another case in point. $^{78}$

The third question is what the structural organization of RSS is and how it is linked to ruling party (BJP) in India? The RSS is the part of the larger Sangh Parivar. This greater Sangh Privar combines a number of right wing Hindu organizations in India and throughout the Hindu diaspora. ${ }^{79}$ However, there are three noteworthy organizations to include the RSS, the Vishwa Hindu Prishad (VHP) and the BJP. Although these organizations have different constitutions, organizational structures and work patterns, there remain common threads between the three organizations in terms of membership, ideology and agendas of action. ${ }^{80}$ They also tend to overlap with the RSS playing a parental role. One can argue that within the Sangh Parivar (family) there is a division of work between the 'cultural' RSS, the 'political' BJP and the 'religious' VHP but, under the umbrella of the Sangh Parivar leadership, they work in close harmony and are well-knitted together with the Hindutva ideology. ${ }^{81}$

${ }^{76}$ Vijaya, Taruna. Saffron Surge: India's Re-emergence on the Global Scene and Hindu Ethos. New Delhi: Har- Anand Publications, 2008.

${ }^{77}$ Shashank Bengali and Juan Perez Jr. India bans 'vulgar' book by University of Chicago scholar. Chicago Tribune. February 2014. Accessed August 5, 2014. http://articles.chicagotribune.com/2014-02-13/news/chi-india-book-ban-wendy-doniger20140213_1_penguin-group-hinduism-chicago-scholar.

${ }^{78}$ Ibid.

${ }^{79}$ Marty, Martin.2014. “Hindu Fundamentalism”. Huffington Post. May 19. Accessed August 5, 2014. http://www.huffingtonpost.com/martin-marty/hindu-fundamentalism _b_5352547.html.

${ }^{80}$ Ibid.

${ }^{81}$ Ibid. 
From 1925-1947, the RSS remained a non-political entity in the absence of a political face. This non-political orientation can be attributed to the conception of the RSS's role by its leaders like M.S. Golwalkar, who viewed politics as the enemy which threatened the very existence of the RSS. ${ }^{82}$ However, during this period, the RSS kept trying to influence the only Hindu political entity of the Indian National Congress on prevalent political issues, like the partition of the British India and non-cooperation with Muslims, through a non-political face. Overall, from 1925-1947, the RSS did not have a readily identified political face or any political patronage from an aligned political force. However, it provided an opposition front to the Indian National Congress and the Muslim League. ${ }^{83}$ The RSS was in its formative years as a minor political force and was still searching for real clout and political identity within Indian politics.

In the second phase, from 1947-1980, the RSS evolved politically and structurally. After the lifting of the first ban on the RSS in 1951, it created its first political wing named Bharitiya Jana Sangh (BJS). The BJS not only enabled the RSS to gain some indirect political clout but also allowed it to disseminate Hindutva ideology. ${ }^{84}$ The BJS stated its "fundamentals" as "one country, one nation, one culture and the rule of law" which were very much in line with the RSS ideas. ${ }^{85}$ The RSS, through this political platform, was able to project its agenda successfully. However, the BJS did not rise to a national

${ }^{82}$ Kulkarni, Sudheendra. Book Review on "Terrifying Vision: M.S. Golwalkar, the RSS and India”. April 2007, accessed August 10, 2014 .http://www.esamskriti.com/essay-chapters/Terrifyingvision -M-S-Golwalkar,-the-RSS-ad-India--1.aspx.

${ }^{83}$ Bose, Anuja. "Hindutva and the Politicization of Religious Identity in India”, Journal of Peace, Conflict and Development, Issue 13, (February 2009). Accessed July 292014.

www.peacestudiesjournal.org.uk_1.

${ }^{84}$ Busch, Carsten. "The Policy of the Bharatiya Janata Party, 1980 and 2008: Possible Influence of Hindu Nationalism on Indian Politics” (master's thesis, US Naval Post Graduate College, 2009), accessed August 4, 2014, http://calhoun.nps.edu/handle/10945/4765.

${ }^{85}$ Ibid. 
stage despite its popular nature amongst the masses. ${ }^{86}$ The BJS later served as a launch pad for creation and establishment of the BJP. ${ }^{87}$

The time period between 1980 and 2014 was the most crucial for the consolidation and expansion of the RSS. After the breakdown of the Janata party, the former members of the BJS founded the Bharatiya Janata Party in 1980. The RSS started expanding its agenda at the national level with the establishment of the BJP. BJP started functioning as the political wing of a Hindu fundamentalist RSS. The RSS enjoyed significant popular support in Indian society which enabled the BJP to establish a national government twice in India between 1980 and 2014. During its first tenure, the BJP did not show its nationalistic face completely under the leadership of the Atal Bihari Vajpayee. However, now under the leadership of Narinder Modi, the BJP as the political arm of the RSS, wants to achieve the main goal of transforming Hindutva ideology into the political realm. The transformation will enable the RSS to reform India into a Hindu Rashtra by changing India's national identity. This fact is evident from the political manifesto of the BJP during the 2014 elections. ${ }^{88}$

The fourth question is how will the RSS, strongly linked with BJP under Narinder Modi, impact Indian policy towards Pakistan? The RSS has successfully influenced Indian policy towards Pakistan since its creation. This influence increased significantly with the rise of Narinder Modi as Prime Minister of India in May 2014. ${ }^{89}$ Being a hardcore and longtime associate of the RSS as well as owing to his antiPakistan position, Narinder Modi is likely to promote the Hindutva ideology, seek to re-establish the notion of Hindu Rashtra and take an extreme political and military stance towards Pakistan. ${ }^{90}$

${ }^{86}$ Ibid.

${ }^{87}$ Ibid.

${ }^{88}$ Gopal, Priyamvada.2014. "Narinder Modi is the face of Hindu Extremism” Gulf News, April 14. Accessed August 5, 2014. http://gulfnews.com/opinions/columnists/narendra-modi-is-the-face-ofhindu-extremism-1.1319340.

${ }^{89}$ Ibid.

${ }^{90}$ Ibid. 
From 1925-1947, the RSS continued to maintain its anti-Muslim stance. This anti-Muslim stance later transformed into an anti-Pakistan agenda after the partition of British India and was in consonance with its core ideology and the teachings of its founding fathers. ${ }^{91}$ The RSS, in the absence of a requisite political standing and due to the non-political orientation, could only attempt to partly influence the Indian National Congress in its stance towards the partitioning plan of the British India. The RSS remained hostile even to the idea of the partition of the British India and creation of Pakistan as a Muslim state. ${ }^{92}$ Mahatma Gandhi was assassinated by a fundamentalist member of the RSS due to Gandhi's cooperation with the leadership of the Muslim League which worked toward the goal of an independent Pakistan. ${ }^{93}$

The RSS continued to maintain its clout with the help of its first political face BJS and other Hindu nationalist organizations like VHP after the partition of British India. Throughout the period of 1947 to 1980, the real rise of the RSS aligned political forces did not surface in India but the RSS maintained its nationalistic position through its political front. The BJS remained a clear opponent of Pakistan and the efforts of the Jammu and Kashmir to achieve independence from India. ${ }^{94}$ This antiPakistan posture was also intense due to the three wars in this time period i.e., 1948, 1965 and 1971.

The third phase between 1980 and 2014 saw the rise of the RSS to its zenith with BJP becoming a concrete political force under the leadership of Narinder Modi. Indian politics saw the monopoly of

${ }^{91}$ Kulkarni, Sudheendra. Book Review on "Terrifying Vision: M.S. Golwalkar, the RSS and India”. April 2007. ), accessed August 10, 2014 .http://www.esamskriti.com/essay-chapters/Terrifyingvision-M-S-Golwalkar,-the-RSS-ad-India--1.aspx.

${ }^{92}$ Levy, Guenter "Militant Hindu Nationalism: The Early Phase” (research project, University of Massachusets, 1967), accessed August 10, 2014. http://www.dtic.mil/dtic/tr/fulltext/u2/654932.pdf.

${ }^{93}$ Sharma, Jyotirmaya. “Terrifying Vision: M.S. Golwalkar, the RSS and India”. Penguin Viking Press. 2007.

${ }^{94}$ Busch, Carsten. “The Policy of the Bharatiya Janata Party, 1980 and 2008: Possible Influence of Hindu Nationalism on Indian Politics” (master's thesis, US Naval Post Graduate College, 2009), accessed August 4, 2014, http://calhoun.nps.edu/handle/10945/4765. 
Indian National Congress at national level till 1980s. ${ }^{95}$ Through its non-aligned stance, secular agenda, and pre-partition political traditions, the Indian National Congress remained successful in its domination of Indian politics. The political scene, however, changed after the creation of the BJP in $1980 .{ }^{96}$ The BJP was created to transform the Hindutva ideology of the RSS into a political reality. ${ }^{97}$ After initial failures, the BJP was able to form a coalition government in India from 1998-2004. ${ }^{98}$ The BJP did not resort to a purely nationalist stance during this tenure and actually adhered to a peace agenda with Pakistan. Initially, in 1980, the BJP replaced BJS and started enhancing its popular support base through the RSS. ${ }^{99}$ This time period also observed the demonstration of nuclear power by India in 1998 under the BJP government. ${ }^{100}$ Real change occurred when Narinder Modi became the prime minister of India after May 2014 elections. ${ }^{101}$ During these elections, the BJP applied its hardcore Hindu Nationalistic agenda to garner public support in India. ${ }^{102}$ The political manifesto of the BJP was completely influenced by the

${ }^{95}$ Ibid.

${ }^{96}$ Ibid.

${ }^{97}$ Christophe Jaffrelot, The Hindu Nationalist Movement and Indian Politics (New Delhi: Penguin Books, 1996), 40.

${ }^{98}$ Ibid.

${ }^{99}$ Busch, Carsten. "The Policy of the Bharatiya Janata Party, 1980 and 2008: Possible Influence of Hindu Nationalism on Indian Politics” (master’s thesis, US Naval Post Graduate College, 2009), accessed August 4, 2014, http://calhoun.nps.edu/handle/10945/4765.

${ }^{100}$ Hindutva: The Great Nationalist Ideology. The Official BJP Site, http://www.bjp.org/index.php?option=com_content\&view=article\&id=369:hindutva-the-great-nationalistideology\&Itemid=501. Accessed 25 July, 2014.

${ }^{101}$ Gowen, Annie.2014. "Hindu Nationalist Sworn Narinder Modi in as India’s Prime Minister”. Washington Post, May 26. Accessed August 2, 2014. http://www.washingtonpost.com/world/hindunationalist-narendra-modi-sworn-in-as- indias-prime-minister/2014/05/26/d6f9ba54-25a6-48ac-9693932132416cf6_story.html.

102 Hindutva: The Great Nationalist Ideology. The Official BJP Site, http://www.bjp.org/index.php?option=com_content\&view=article\&id=369:hindutva-the-great-nationalistideology\&Itemid=501. Accessed 25 July, 2014. 
RSS ideology. ${ }^{103}$ This manifesto included the construction of the 'Hindu Ram Temple' in place of the 'Babri Mosque’, the abolition of Article 340 in Jammu and Kashmir, a tougher stance toward Pakistan and a pronounced exertion of India as a regional and global power. ${ }^{104}$ Narinder Modi took even a more nationalistic stance towards Pakistan after becoming Prime Minister. Modi is a staunch nationalist with a vehement anti-Pakistan stance due to his personnel orientations and ideological lineage. ${ }^{105}$ Andy Marino in his book "Narinder Modi: The political Biography”, describes Modi in the words of an old associate "Narendra was charged up and voluble on how all Pakistanis should be decimated”. ${ }^{106}$ Modi has long been associated with the RSS since his childhood and the organization serves as his ideological mentor. ${ }^{107}$ The federal cabinet selected by Narinder Modi is closely linked to the RSS. ${ }^{108}$ Recent Indian efforts to increase its regional dominance, the cancellation of Secretary level talks with Pakistan, cease-fire violations along Line-of-Control and working boundary with Pakistan, and provocative statements by Narinder Modi against Pakistan have exposed the true nature of the Modi-RSS-BJP nexus. ${ }^{109}$ The current Indian government as influenced by the RSS ideology is likely to show "geopolitical and military manhood”, especially oriented towards Pakistan. ${ }^{110}$ The Modi government continues to enhance its

103 Ibid.

${ }^{104}$ Lodhi, Maleeha .2014. ”Futility of Coercive Diplomacy”. The News, Pakistan. October 14. Accessed August 2 2014. http://www.thenews.com.pk/Todays-News-9-280866-Futility-of-coercivediplomacy. 2013.

${ }^{105}$ Marino, Andy. “Narinder Modi: The political Biography”, Harper Collins Publishers, India,

$$
\begin{aligned}
& { }^{106} \text { Ibid. } \\
& { }^{107} \text { Ibid. }
\end{aligned}
$$

${ }^{108}$ Nagi, Saroj 2014. Cabinet Reshuffle: A Sarkar, by and for Modi, bound together by the RSS. First Post. November 9, 2014. http://www.firstpost.com/politics/cabinet-reshuffle-sarkar-modibound-together-rss-1794869.html. Accessed 15 November, 2014.

${ }^{109}$ Lodhi, Maleeha .2014. ”Futility of Coercive Diplomacy”. The News, Pakistan. October 14. Accessed August 2 2014. http://www.thenews.com.pk/Todays-News-9-280866-Futility-of-coercivediplomacy.

$$
{ }^{110} \text { Ibid. }
$$


diplomatic efforts to isolate Pakistan in the region. This fact is evidenced by Modi’s outreach to neighboring countries and high level engagements with all regional countries while deliberately excluding Pakistan. ${ }^{111}$

The fifth question is whether the RSS is linked to the Indian Military? No concrete evidence is currently available to establish formal linkages between the RSS and the Indian military. But, there is evidence to establish casual and informal links between the RSS and the Indian military hierarchy. ${ }^{112}$ Owing to its organizational structure and popular support in rural Indian society, the RSS also maintains its contacts at the grass roots echelons in the Indian military. Therefore, direct and indirect linkages direct between the RSS and the Indian military cannot be denied.

The RSS maintains a young volunteer force as a national service force which serves as a reserve military force. ${ }^{113}$ There are instances where the strong linkages between the officer cadre of the Indian military and the RSS were established. ${ }^{114}$ General V.K.Singh, an ex-chief of staff of the Indian army, was elected as Member of Indian Lok Sabha (Parliament) on the BJP platform and is a minister of state in Narinder Modi’s cabinet. Gen V.K.Singh has ultra nationalist orientations and a hyper stance against Pakistan, and he is an RSS activist and a close associate of Narinder Modi. ${ }^{115}$ Singh in his recent book ‘Courage and Conviction' provides some insights into the linkages between the Indian military and the

\section{${ }^{111}$ Ibid.}

${ }^{112}$ Gokhale , Nitin. "Lt Colonel Purohit: Did the Army sell short an effective officer? June 2012. Accessed October 2 2014.http://www.ndtv.com/article/india/lt-colonel-purohit-did-the-army-sell-shortan-effective-officer-237995.

${ }^{113}$ Curran, Jean A., Jr. “The RSS: Militant Hinduism”. Far Eastern Survey 19, no.10 (May 1950). Accessed August 4, 2014. http://www.jstor.org/stable/3023941.

${ }^{114}$ Gokhale , Nitin. "Lt Colonel Purohit: Did the Army sell short an effective officer? June 2012. Accessed October 2 2014. http://www.ndtv.com/article/india/lt-colonel-purohit-did-the-army-sell-shortan-effective-officer-237995.

${ }^{115}$ Kumar. V.K. “Courage and Conviction. Aleph Book Company, 2013. 
RSS. ${ }^{116}$ The dubious involvement of Indian army officers in the 'Samjhota Express bombing' in 2007 and the 'Malegaon Mosque Incident' in 2006 also point towards the underlying nexus between the Indian military and the RSS. ${ }^{117}$

The sixth question is can the RSS impact Indian military strategy? Owing to its close linkages with the Indian political leadership and some direct and indirect linkages with the Indian military hierarchy, the RSS has potential capability to directly influence or indirectly impact the Indian military strategy towards Pakistan. The RSS has always been successful in portraying Pakistan as the real threat to the Indian state through its anti-Muslim ideological lens, at home and abroad. The Hindutva ideology of the RSS in itself envisages the non-existence of Pakistan as a separate state in South Asia and the RSS considers the creation of Pakistan as a betrayal of the principle of a single united Hindu nation. ${ }^{118}$

The BJP government has always blamed the previous Congress government for a benign military response towards Pakistan, especially after the 2006 Mumbai Terrorist Attacks. ${ }^{119}$ The present government is likely to change its posture towards Pakistan if it is truly being highly influenced by the RSS agenda. Recent diplomatic pressure from India, coupled with the aggressive military of multiple cease fire-violations serve as evidence that India is likely to change its military stance towards Pakistan in a more assertive and aggressive manner. ${ }^{120}$ Recent statements by Modi, in which he propagates teaching Pakistan a lesson through the language of a 'Bullet' instead of bilateral talks. ${ }^{121}$ His guidance issued to the

116 Ibid.

${ }^{117}$ Hindu Extremist Confess Involvement in Samjhota Express Bombing. The Tribune Pakistan. January 2011. Accessed August 2 2014. http://tribune.com.pk/story/100465/hindu-extremist-confessesinvolvement-in-samjhauta-express-bombing/.

118 Marty, Martin.2014. “Hindu Fundamentalism”. Huffington Post. May 19. Accessed August 5, 2014. http://www.huffingtonpost.com/martin-marty/hindu-fundamentalism _b_5352547.html.

${ }^{119}$ Ibid.

${ }^{120}$ Lodhi, Maleeha.2014. “Futility of Coercive Diplomacy”. The News, Pakistan. October 14. Accessed August 2 2014. http://www.thenews.com.pk/Todays-News-9-280866-Futility-of-coercivediplomacy.

${ }^{121}$ Ibid. 
ministerial cabinet to teach Pakistan a befitting lesson is likely to serve as guidance to the Indian military hierarchy and significantly influences an already aggressive Indian military strategy towards Pakistan resulting in heightened tensions between both countries. In addition to an increasingly aggressive military posture, the speedy buildup of military hardware and nuclear capability by India under the premiership of Modi is likely to shift the balance of power in India's favor. This change in the balance of power will create a difficult security dilemma for Pakistan, compelling it to resort to an arms race. ${ }^{122}$

Evidence shows that the RSS was found on the ideology of Hindutva in 1925. The aim of this organization was to re-invigorate the Hindu nationalism against the backdrop of the independence movement of India from the British Raj. The founding fathers of the RSS were also significantly inspired by the prevalent fascist trends in Nazi Germany. So they made use of the Hindutva ideology to spark a social movement in British India in order to propagate the supremacy of the Hindu religion and culture while undermining Muslims in British India. Hindutva ideology is the common narrative which runs throughout the entire history of the RSS since its creation. The RSS has always kept the Hindutva ideology at its core with the purpose of gaining popular support for promoting its nationalist agenda. ${ }^{123}$

The history of the RSS proves the organization to be a religious fundamentalist institution. This organization was banned thrice by different Indian governments due to its ultra nationalist, militant and violent overtones. ${ }^{124}$ This organization kept increasing its political and popular clout in India and has survived multiple bans by Indian governments. The RSS was also involved in the Gujarat Riots under the political patronage of the state government. Facts also prove that the RSS has taken a permanent antiMuslim and anti-Pakistan stance. ${ }^{125}$ After the appointment of Narinder Modi the RSS has increasingly

${ }^{122}$ Lodhi, Maleeha.2014. "Futility of Coercive Diplomacy”. The News, Pakistan. October 14. Accessed August 2 2014. http://www.thenews.com.pk/Todays-News-9-280866-Futility-of-coercivediplomacy.

\footnotetext{
${ }^{123}$ Marty, Martin.2014. “Hindu Fundamentalism”. Huffington Post. May 19. Accessed August 5, 2014. http://www.huffingtonpost.com/martin-marty/hindu-fundamentalism _b_5352547.html.

124 Ibid.

${ }^{125}$ Ibid.
} 
started to flex its muscles in Indian society through their demands to transform the Indian society along Hindu nationalist orientations. ${ }^{126}$

The RSS was created as a non-political entity as per the vision of its founding fathers. Following the independence of India, the RSS created its political wing in the shape of BJS in 1951 to project its strategic objectives. ${ }^{127}$ Sangh Parivar created another ideologically aligned organization of the VHP in 1964. ${ }^{128}$ BJS was not really successful in transforming its popular support into political power and it revived itself as BJP in $1980 .{ }^{129}$ The troika of the RSS, VHP and the BJP proved to be very effective in promoting the Hindu nationalistic agenda in India. The improvement in BJP's power grip over politics enabled the RSS to enhance its agenda by cultivating individuals in political hierarchy of India through mainstream politics of the BJP.

The recent rise of Narinder Modi as a hardcore RSS elite prime minister of India brought the RSS into limelight. He was always viewed with suspicion due to his nationalist orientations, controversial role in the anti-Muslim 'Gujrat Riots', his anti-Pakistan stance and the political agenda of the BJP for the 2014 elections. ${ }^{130}$ Recent coercive diplomacy, regional outreach, cease-fire violations and volatile statements

${ }^{126}$ Gopal, Priyamvada.2014. "Narinder Modi is the face of Hindu Extremism” Gulf News, April 14. Accessed August 5, 2014. http://gulfnews.com/opinions/columnists/narendra-modi-is-the-face-ofhindu-extremism-1.1319340.

${ }^{127}$ Busch, Carsten. “The Policy of the Bharatiya Janata Party, 1980 and 2008: Possible Influence of Hindu Nationalism on Indian Politics” (master's thesis, US Naval Post Graduate College, 2009), accessed August 4, 2014, http://calhoun.nps.edu/handle/10945/4765.

${ }^{128}$ Ibid.

129 Ibid.

${ }^{130}$ Gopal, Priyamvada.2014. "Narinder Modi is the face of Hindu Extremism” Gulf News, April 14. Accessed August 5, 2014. http://gulfnews.com/opinions/columnists/narendra-modi-is-the-face-ofhindu-extremism-1.1319340. 
by the Modi government on Kashmir issue substantiate his continuous pursuit of the RSS influenced Hindu Nationalist agenda. ${ }^{131}$

No concrete evidence exists to prove the formal linkage between the RSS and the Indian military. However, since independence, the Indian military traditionally accepts the principle of civilian supremacy in national policy formulation and is likely to continue in India for the foreseeable future as well. ${ }^{132}$ The BJP is likely to successfully enforce its policy without any hindrance owing to civ-military power structure and congruence of threat perception by elected Indian political governments and Indian military. ${ }^{133}$ The RSS is likely to exercise its indirect influence over the military hierarchy of India through this arrangement. ${ }^{134}$ Close association between the RSS and the Indian military hierarchy, both retired and active duty personnel, continues to exist. ${ }^{135}$ The initial tone of Narinder Modi, his cabinet selection and policy statements tend to prove that the RSS, through BJP and the present leadership in Indian government can directly influence and indirectly impact the Indian military strategy towards Pakistan. ${ }^{136}$ Any anti-Pakistan agenda by the BJP led government is likely to influence and shape the military strategy of India against Pakistan. This case study has scrutinized the history, ideology, the role of the RSS in India from 1925 to 2014. Through the structured and focused methodology, the questions were addressed

${ }^{131}$ Lodhi, Maleeha .2014. ”Futility of Coercive Diplomacy”. The News, Pakistan. October 14. Accessed August 2 2014. http://www.thenews.com.pk/Todays-News-9-280866-Futility-of-coercivediplomacy.

${ }^{132}$ Kotera, Bhimaya. “Civil Military Relations: A Comparative Study of India and Pakistan”, (Dissertation for Rand Graduate School, 1997). Accessed 25 October, 2014. http://www.rand.org/content/dam/rand/pubs/rgs_dissertations/2006/RGSD136.pdf.

133 Ibid.

${ }^{134}$ Ibid.

${ }^{135}$ Gokhale, Nitin. "Lt Colonel Purohit: Did the Army sell short an effective officer? June 2012. Accessed October 2 2014. http://www.ndtv.com/article/india/lt-colonel-purohit-did-the-army-sell-shortan-effective-officer-237995.

${ }^{136}$ Lodhi, Maleeha, 2014. ”Futility of Coercive Diplomacy”. The News, Pakistan. October 14. Accessed August 2 2014. http://www.thenews.com.pk/Todays-News-9-280866-Futility-of-coercivediplomacy. 
within the construct of three phases i.e. 1925 to 1947, 1948 to1980 and 1980 to 2014. The study was able to identify some continuities in the nature and role of the RSS. The case study simultaneously highlighted some evolutions in the nature of the RSS.

Initially created as a volunteer service organization to re-invigorate Hindu nationalism during the Indian independence movement, the RSS soon displayed its fascist, religious and communal orientations. Though a non-entity while making use of the Hindutva ideology, the RSS started influencing the Indian politics since its creation. In phase one, 1925-1947, the RSS was very open in its anti-Muslim stance during its formative days, taking the shape of a Hindu fundamentalist organization.

The second phase saw the expansion of the RSS's political clout. It initially created the BJS as its political wing in 1951, but due to its unsuccessful nature the same was transformed into the larger BJP in 1980. Meanwhile, the RSS started cultivating the political elite of the BJP while constantly influencing Indian politics. The RSS was able to implement the Hindu nationalist agenda through the political clout of the BJP with an aggressive anti-Pakistan narrative throughout its history. The BJP won the 2014 elections on the basis of the RSS's influenced political agenda, which appealed the Indian masses. Narinder Modi's appointment as the prime minister of India has seen the RSS's influence reach its zenith. It has already started showing the nationalist nature of its political agenda. These overtures have started to shape the Indian policy towards Pakistan. Hence, the RSS-Modi-BJP nexus is fully capable of changing the Indian military strategy towards Pakistan, with a more aggressive, bold and coercive approach. 


\section{Findings and Analysis}

The structured focused method of the case study helped to study the RSS’s history and ideology throughout the course of its development as a frontline ideological entity. The ideology is strongly aligned with the political entity of the BJP. It also assisted in highlighting its changing relationships with the Indian politics and policy both directly and indirectly since the creation of the RSS in 1925 to the appointment of Narinder Modi as Indian Prime Minister in 2014. The case study also explored the linkages of the RSS with individuals in the political and military hierarchies of India as well as how these individual agents helped drive the agenda of the RSS in close coordination with its political wing; the BJP. The case study also focused on the agent-structure relationship while exploring the role of Narinder Modi in implementing the ideology of the RSS and the political agenda of the BJP after his unchallenged rise as the prime minister of India. ${ }^{137}$ The study also focused on Pakistan when scrutinizing the RSS's influences on India’s policy.

The RSS was founded on the ideology of Hindutva which remains to be its source of existence since its creation. Hindutva drives individual and collective actions of the RSS and the BJP. The rise of Narinder Modi as India's prime minister is likely to increase the role of Hindutva ideology in Indian internal and external affairs. Initially, founded as a national volunteer service organization, the role of RSS has been that of a Hindu nationalist organization throughout the course of its history. The RSS took a fundamentalist outlook in 1992 during the desecration and demolition of the historic Babri Mosque. ${ }^{138}$ This transformation did not stop with its fundamentalist role but went a step further to assume a militant role in 2002 during the Muslim massacre in the Indian state of Gujarat. ${ }^{139}$ Presently the RSS is a Hindu fundamentalist organization with militant overtones. Although the RSS was created to be a non-political

${ }^{137}$ Brown, Chris, and Kirsten Ainley, Understanding International Relations. Basingstoke: Palgrave Macmillan, 2009.

${ }^{138}$ Marty, Martin.2014. “Hindu Fundamentalism”. Huffington Post. May 19. Accessed August 5, 2014. http://www.huffingtonpost.com/martin-marty/hindu-fundamentalism _b_5352547.html.

${ }^{139}$ Ibid. 
entity, it has its nature and combined together with different political entities. Initially it created the BJS as its political wing in 1951 which provided the platform necessary to expand the political wing of the RSS in the shape of the BJP in 1980. ${ }^{140}$ Presently, the RSS controls Indian politics through the BJP. Following election of Narinder Modi as the prime minister of India, the Indian policy towards Pakistan has undergone a major strategic shift. The Indian behavior underwent a rapid transition from cooperation to coercion, while trying to isolate Pakistan both diplomatically and economically. From a military perspective though, there is no evidence to suggest that Indian military hierarchy is directly linked with the RSS but that the RSS definitely influences the Indian military through the Hindutva ideology. Historically, however, there were instances when the RSS maintained direct linkages within the serving military officers in the Indian Military. Through these ideological linkages and the strong political control of Indian military by the BJP, India has abruptly changed its military strategy towards Pakistan following the rise of Narinder Modi as prime minister. Narinder Modi’s reiteration to teach Pakistan a lesson through the language of 'Bullet' speaks volumes about the impending change in the thought processes of the Indian military. ${ }^{141}$ Recently, the Indian military was directed to operationalize its plans for a two-front war while focusing on Pakistan. ${ }^{142}$

Deriving its strength from the Hindutva ideology, the RSS was successful in expanding itself as a strong ideological entity India. Though propagated otherwise, the RSS - in addition to its ultra-nationalist nature - always had a fundamentalist and militant outlook. Meanwhile, it maintained close linkages with the Indian politics initially through the establishment of BJS and then through the BJP since its creation in 1980. The RSS attained its zenith with the appointment of Narinder Modi as Indian Prime Minister

\footnotetext{
${ }^{140}$ Busch, Carsten. "The Policy of the Bharatiya Janata Party, 1980 and 2008: Possible Influence of Hindu Nationalism on Indian Politics” (master's thesis, US Naval Post Graduate College, 2009), accessed August 4, 2014, http://calhoun.nps.edu/handle/10945/4765.

${ }^{141}$ Lodhi, Maleeha, 2014. ”Futility of Coercive Diplomacy”. The News, Pakistan. October 14. Accessed August 2 2014. http://www.thenews.com.pk/Todays-News-9-280866-Futility-of-coercivediplomacy. 142 Ibid.
} 
following the BJP's sweeping victory in the Indian elections of May 2014. ${ }^{143}$ Immediately after taking over, Narinder Modi rapidly changed the Indian policy towards Pakistan. This shift was not only observed at the policy level but at the military level as well.

During the research, the first hypothesis was that with the Hindu nationalist ideology of the Hindutva, the RSS will incite nationalistic fervor in India. The BJP will indirectly impact the Indian policy towards Pakistan under Prime Minister Narinder Modi with his close links to the party. The research findings strongly suggest that the RSS relies on the Hindutva ideology to garner public and political support in the Indian society and electorate. ${ }^{144}$ The RSS constantly increased its political clout in Indian politics through a particular political wing. Initially it was the BJS until the 1970s, which was then replaced by a stronger and mature BJP in 1980. ${ }^{145}$ The BJP ran 2014 elections with a nationalist agenda and political manifesto. In the 2014 election process, the RSS was able to achieve its zenith with the appointment of Narinder Modi as the prime minister of India. Soon after assumption of office, Narinder Modi brought a rapid shift in India’s policy, especially towards Pakistan. A sudden Indian shift from cooperation to coercion, efforts for diplomatic isolation of Pakistan and exertions to change the political status of Kashmir are a few examples which reveal the level of influences enjoyed by the RSS on Indian policy making. Therefore, the evidence presented during this research strongly suggests that the first hypothesis is fully supported. The RSS is likely to continue to expand its influences on Indian policy towards Pakistan, especially under the staunch leadership of Narinder Modi owing to the supremacy and

143 Gowen, Annie, 2014. “Hindu Nationalist Sworn Narinder Modi in as India’s Prime Minister .26 May 2014. The Washington Post. Accessed 2 August, 2014. http://www.washingtonpost.com/world/hindu-nationalist-narendra-modi-sworn-in-as-indias-primeminister/2014/05/26/d6f9ba54-25a6-48ac-9693-932132416cf6_story.html.

${ }^{144}$ Marty, Martin.2014. “Hindu Fundamentalism”. Huffington Post. May 19. Accessed August 5, 2014. http://www.huffingtonpost.com/martin-marty/hindu-fundamentalism _b_5352547.html.

145 Busch, Carsten. "The Policy of the Bharatiya Janata Party, 1980 and 2008: Possible Influence of Hindu Nationalism on Indian Politics” (master's thesis, US Naval Post Graduate College, 2009), accessed August 4, 2014, http://calhoun.nps.edu/handle/10945/4765. 
appeal of the Hindutva ideology. The RSS is also likely to push the BJP government to implement all its RSS linked political agendas without any hesitation or fear of domestic and foreign reactions. The case also presents an ideal example of the agent-structure relationship wherein the RSS-BJP-Modi nexus is likely to not only have a significant amount of influence on the domestic and foreign policy of India but also long-term implications for regional stability within the context of India-Pakistan relations. ${ }^{146}$ The research also reveals the role of the identities, ideologies and internal models of agents/meta-agents in the two level game in generating responses to actors in international relations. ${ }^{147}$ Narinder Modi, a strong believer of the RSS's Hindutva ideology is linked to the structure of the BJP and is likely to push forward the RSS agenda to re-claim India's Hindu identity. Modi’s actions will create a cognitive tension in Indian society and also generate implications for Pakistan within a regional context.

The second hypothesis is that, with strong linkages to the Indian Military and Government, the RSS is likely to influence military strategy of India while generating security threats for Pakistan. The Indian national security objectives can be subdivided into “three concentric circles”; India’s immediate neighborhood, its extended neighborhood, and the global stage. ${ }^{148}$ Within these three circles, India is likely to pursue different approaches. On the global stage, India is likely to abandon its policy of nonalignment and align more with USA while playing a main role in USA's re-balancing to Asia-Pacific. India's role on the global stage will also increase due to its emergence as an economic power. In the extended and immediate neighborhood, India is likely to engage more in order to dominate the regional political and ensure its security objectives. India is likely to exclude Pakistan within the immediate neighborhood from any kind of such engagement, especially on mutually agreed terms. The findings from

\footnotetext{
${ }^{146}$ Brown, Chris, and Kirsten Ainley, Understanding International Relations. Basingstoke: Palgrave Macmillan, 2009.

${ }^{147}$ Putnam, Robert D. "Diplomacy and Domestic Politics: The Logic of Two-Level Games.” International Organization 42, no. 3 (1988): 427-460.

${ }^{148}$ Bagia, Amrit. Understanding India’s National Security Objectives through Indian Sources. (master's thesis, George Town University, 2011). Accessed 12 August, 2014. https://m.repository.library.georgetown.edu/bitstream/handle/10822/553439/bagiaAmrit.pdf?sequence=1.
} 
the research suggest that RSS is indirectly linked to the Indian military and directly linked to the political hierarchy of India which will continue to aggressively shape the Indian military strategy towards Pakistan. Immediately after the appointment of Narinder Modi as prime Minister of India, a change in Indian military behavior was observed. Statements by the national security staff and the Indian military elite reveal that the India is likely to embark on a mission to prove its 'Masculine Power' in the words of Pakistan's former ambassador to US and UK. ${ }^{149}$ Moreover, the pursuit of a very heavy defense oriented procurement plan combined with overtures to change the political status of the disputed region of Kashmir, and the change of military posture along the Line of Control on India-Pakistan border indicates the evolving dynamics of India’s military strategy. Owing to the guidance provided by the Modi administration on national security, the Indian military will embark on a mission to operationalize the two front war plans with a focus on Pakistan.

All these developments are likely to compel Pakistan to change its response from a point of appeasement to a point of defiance at the political and military level. The continuing push to isolate and pressurize Pakistan - at both political and military levels - by India on her own terms is likely to induce a belligerent response on Kashmir from Pakistan. Conversely, Modi’s heavy reliance on the ideological base of the RSS may prove to be harmful for a once secular and non-aligned nature of Indian political affairs. The ‘Hindus Only’ notion will, for sure, threaten the heterogeneous society of India, giving rise to the prevalent fissiparous tendencies in the 'Seven Sister States' and the 'Red Corridor' in the union of India.

Focus remained on the RSS’s history, ideology and its influences on the Indian policy towards Pakistan during the research. While exploring these aspects, research relied on structure focused questions to collect evidence to craft the findings of the research to support or challenge the two overarching

${ }^{149}$ Lodhi, Maleeha.2014. ”Futility of Coercive Diplomacy”. The News, Pakistan. October 14. Accessed August 2, 2014. http://www.thenews.com.pk/Todays-News-9-280866-Futility-of-coercivediplomacy. 
hypothesis. The accumulated evidence and the findings of the research strongly support the hypotheses of research. Based on the findings of the research, certain inferences were also drawn in the India-Pakistan context and research anticipates an assertive global India with combative and antagonistic tendencies towards Pakistan. 


\section{Conclusion}

The first purpose of this research was to explore the history of the RSS and determine its ideological base. The second purpose was to discover the linkages between the RSS and Indian political and military hierarchy. Having explored these linkages, both direct and indirect, to the Indian politics and military, a third purpose was to focus on the influences which the RSS has on Indian policy making and military strategy. The fourth purpose was to highlight the major policy and security implications of the RSS-BJP-Modi nexus for Pakistan. The working hypothesis for this research was that the RSS surfaced as a national volunteer movement in British India in 1925. However, its peculiar history, the association with the Hindutva ideology and its role in Indian politics has always been dubious. The recent rise of the BJP under Narinder Modi’s leadership magnifies such apprehensions wherein an extremist RSS will be afforded more living space by the BJP. Hence, an extremist RSS with close linkages to the political and the military elite of India is likely to not only radicalize Indian Society but also influence strategic policy making and military conduct towards Pakistan. Based on the available evidence research strongly suggests that the hypothesis is supported.

The research utilized the method of structured, focused comparison to analyze the case study. The purpose of the specific questions was to standardize the data collection process in order to develop and articulate the case findings. Moreover, dealing with only a certain time period and specific theoretical framework of strategy, policy and military strategy focused the research methodology. The research objective for the study was to determine how the RSS developed as an organization and influenced Indian policy making along with military strategy in three time periods. The time periods analyzed are from 1925 (Establishment of the RSS as a national service organization) to 1947 (the independence of India), from 1947 to May 2014 (The Bharatiya Janata Party’s victory in Indian National elections), and period from the successful nomination of Narindra Modi as India’s prime minister onwards. Several questions derived from the hypotheses guided this research. These questions were embedded in the theoretical perspective and purpose of the research. 
The findings of the research are primarily significant to the policy thinkers, stakeholders and the operational planners in the Pakistan military as well as U.S policy makers. The research also provided an interesting case to study the role of history and ideology in policy making. Moreover, it also provides an interesting case analysis to scrutinize the agent-structure theory and relationship within the academic field of international relation. Being a contemporary case, however, the research is limited to a specific timeframe and had to rely on real-time events. Therefore, certain inferences were also made in the findings of the research. As the events unfold, there may be a likely requirement to update the inferences. The research also opens a number of new vistas for research on the issue like the impact of RSS-BJP-Modi nexus on the domestic politics of India, the impact of the RSS-BJP-Modi nexus on the secular nature of Indian state and also the response options for Pakistan to challenge the negative/assertive influences of RSS-BJP-Modi nexus.

The RSS evolved as a National Volunteer Organization in 1925 in present day India. This organization has always remained under the focus of critics, both local and foreign, due to its role in extremist activities, its ideology, motives, and influences on Indian politics. Owing to these controversies, the RSS was banned twice in India. The recent rise of Narinder Modi to the premiership of India brought the RSS to the forefront of discussion due to his long and controversial association with this organization. Narinder Modi as the Prime Minister of India, has injected additional uncertainties and apprehensions about the future behavior of the Indian politico-military elite. In this context, it became paramount to establish the underlying linkages of the RSS to India's politico-military hierarchy with a view towards drawing inferences for stakeholders in Pakistan. The recent developments within the India-Pakistan context provide a compelling reason to believe that the RSS has the capability to implement its nationalist agenda through the help of BJP’s political power, and encouraged by a strong ideologue like Modi in command. 


\section{Bibliography}

Alexander L. George, Andrew Bennett. Case Studies and the Theory Development in the Social Sciences. 2005.

Bardach, Eugene A Practical Guide for Policy Analysis: The Eightfold Path to More Effective Problem Solving. 2nd ed. (Washington, D.C: CQ Press, 2005).

Bagia, Amrit. Understanding India’s National Security Objectives through Indian Sources. (master's thesis , George Town University, 2011). Accessed 12 August, 2014.

https://m.repository.library.georgetown.edu/bitstream/handle/10822/553439/bagiaAmrit.pdf?sequ ence $=1$.

Berti, Daniela. Hindu Nationalists and local history: From ideology to local lore, accessed August 2, 2014, http://www.fupress.net/index.php/rss/article/download/2462/2297.

Bose, Anuja. "Hindutva and the Politicization of Religious Identity in India”, Journal of Peace, Conflict and Development, Issue 13, (February 2009). Accessed July 29, 2014.

www.peacestudiesjournal.org.uk1.

Brown and Ainley, Understanding International Relations. Basingstoke: Palgrave Macmillan, 2009.

Busch, Carsten. "The Policy of the Bharatiya Janata Party, 1980 and 2008: Possible Influence of Hindu Nationalism on Indian Politics” (master’s thesis, US Naval Post Graduate College, 2009), accessed August 4, 2014, http://calhoun.nps.edu/handle/10945/4765.

Christophe Jaffrelot, The Hindu Nationalist Movement and Indian Politics (New Delhi: Penguin Books, 1996).

Curran, Jean A., Jr. “The RSS: Militant Hinduism”. Far Eastern Survey 19, no.10 (May 1950). Accessed August 4, 2014. http://www.jstor.org/stable/3023941.

Darling, Adrienne K. Fraser. “India Global Ambitions Limited by Regional Reach” (strategy research project, US Army War College, 1998), accessed July 28, 2014.

http://www.dtic.mil/dtic/tr/fulltext/u2/a345883.pdf.

Dolman, Everett. Pure Strategy. The university of Chicago press, 2013.

Flyvbjerg, Bent, Case Study, The Sage Handbook of Qualitative Research, $4^{\text {th }}$ Edition, Thousand Oaks, CA.

Gowen, Annie.2014. “Hindu Nationalist Sworn Narinder Modi in as India’s Prime Minister”. Washington Post, May 26. Accessed August 2, 2014. http://www.washingtonpost.com/world/hindunationalist-narendra-modi-sworn-in-as- indias-prime-minister/2014/05/26/d6f9ba54-25a6-48ac9693-932132416cf6_story.html.

Gopal, Priyamvada.2014. "Narinder Modi is the face of Hindu Extremism”, Gulf News, April 14. Accessed August 5, 2014. http://gulfnews.com/opinions/columnists/narendra-modi-is-the-face-ofhindu-extremism-1.1319340. 
Gokhale, Nitin. "Lt Colonel Purohit: Did the Army sell short an effective officer? June 2012. Accessed October 2 2014.http://www.ndtv.com/article/india/lt-colonel-purohit-did-the-army-sell-short-aneffective-officer-237995.

Hundal, Sunny. 2014. "Hindu nationalists are gaining power in India - Should the West be Worried”, Independent, February 26. Accessed August 1, 2014. http://www.independent.co.uk/news/world/asia/hindu-nationalists-are-gaining-power-in india-and-silencing-enemies-along-the-way-9155591.html.

Hindutva: The Great Nationalist Ideology. The Official BJP Site, http://www.bjp.org/index.php?option=com_content\&view=article\&id=369:hindutva-the-greatnationalist-ideology\&Itemid=501. Accessed 25 July, 2014.

Jaffrelot, Christopher. The Hindu Nationalist Movement and Indian Politics. New Delhi: Penguin Books, 1996.

Kenneth Shouler, Susai Anthony, Is There Hindu Extremism? Net Places digital library, accessed July 30, 2014, http://www.netplaces.com/hinduism/controversies-about-hinduism/is-there-hinduextremism.htm.

Kotera, Bhimaya. “Civil Military Relations: A Comparative Study of India and Pakistan”, (Dissertation for Rand Graduate School, 1997). Accessed 25 October, 2014. http://www.rand.org/content/dam/rand/pubs/rgs_dissertations/2006/RGSD136.pdf.

Kulkarni, Sudheendra. Book Review on “Terrifying Vision: M.S. Golwalkar, the RSS and India”. April 2007.), accessed August 10, 2014 .http://www.esamskriti.com/essay-chapters/Terrifying-visionM-S-Golwalkar,-the-RSS-ad-India--1.aspx.

Kumar. V.K. “Courage and Conviction”. Aleph Book Company, 2013.

Levy, Guenter “Militant Hindu Nationalism: The Early Phase” (research project, University of Massachusets, 1967), accessed August 10, 2014. http://www.dtic.mil/dtic/tr/fulltext/u2/654932.pdf.

Lodhi, Maleeha.2014. ”Futility of Coercive Diplomacy”. The News, Pakistan. October 14. Accessed August 2 2014. http://www.thenews.com.pk/Todays-News-9-280866-Futility-of-coercivediplomacy.

Mahmud, Tariq, 2015. The BJP’s Mission Kashmir. Tribune January 13, 2015. Accessed 20 January, 2015 on http://tribune.com.pk/story/820771/the-bjps-mission-kashmir/

Marty, Martin.2014. “Hindu Fundamentalism”. Huffington Post. May 19. Accessed August 5, 2014. http://www.huffingtonpost.com/martin-marty/hindu-fundamentalism _b_5352547.html.

Marino, Andy. “Narinder Modi: The political Biography”, Harper Collins Publishers, India, 2013.

Merriam -Webster Dictionary. http://www.merriam-webster.com/dictionary/strategy. Accessed on 6 August, 2014. 
Mehta, Mandavi. “The Role of Hundutva in Indian Politics”. The South Asia Monitor, no.55, (February 2003). Accessed 5 August, 2014. http://www.ciaonet.org/pbei/csis/sam/sam55/.

Nagi, Saroj 2014. Cabinet Reshuffle: A Sarkar, by and for Modi, bound together bythe RSS. First Post. November 9, 2014. http://www.firstpost.com/politics/cabinet-reshuffle-sarkar-modi-boundtogether-rss-1794869.html. Accessed 15 November, 2014.

Nussbaum, Martha C. The Clash Within: Democracy, Religious Violence, and India's Future. USA: Harvard University Press, 2007.

Pathak, K. K. Of Jaswant Singh, the BJP and the RSS. Mumbai: The Rajaji Foundation, 2010. Accessed 10 August, 2014. http://www.freedomfirst.in/freedom-first/pdf/jaswant-singh-book.pdf.

Putnam, Robert D. “Diplomacy and Domestic Politics: The Logic of Two-Level Games.” International Organization 42, no. 3 (1988).

Swamy, Arun R. "Ideology, Organization and Electoral Strategy of Hindu Nationalism: What's Religion Got to do with it?” Research Paper, Asia Pacific Centre for Security Studies, (March2003).

Accessed August 4, 2014.

http://www.apcss.org/Publications/Ocasional\%20Papers/OPHinduNationalism.pdf.

Shah, Chayanika "Hindu Fundamentalism in India: Ideology, strategies and the experience of Gujrat". Accessed August 3, 2014. http://www.tigweb.org/action-tools/projects/.../07\%20HF\%20in\%20 India.pdf.

Sharma, Jyotirmaya. “Terrifying Vision: M.S. Golwalkar, the RSS and India”. Penguin Viking Press. 2007.

Shashank Bengali and Juan Perez Jr. India bans 'vulgar' book by University of Chicago scholar. Chicago Tribune. February 2014. Accessed August 5, 2014. http://articles.chicagotribune.com/2014-0213/news/chi-india-book-ban-wendy-doniger-20140213_1_penguin-group-hinduism-chicagoscholar.

Satu P. Limaye, Robert G. Wirsing, Mohan Malik, "Religious Radicalism and security in South Asia”. Accessed July 25, 2014.

http://www.apcss.org/Publications/Edited\%20Volumes/ReligiousRadicalism/ReligiousRadicalis mandSecurityinSouthAsia.pdf.

Seshia, Shaila. "Divide and Rule in Indian Party Politics: The Rise of the Bharatiya Janata Party” Asian Survey 38, no.11, (November 1998). Accessed July 25, 2014. http://www.jstor.org/stable/2645684.

Therwath, Ingrid. “Cyber - Hindutva: Hindu Nationalism, the diaspora and the web”. Accessed August 3, 2014. http://www.inter-disciplinary.net/at-the-interface/wpcontent/uploads/2012/06/therwathdpaper.pdf.

Vijaya, Taruna. Saffron Surge: India's Re-emergence on the Global Scene and Hindu Ethos. New Delhi: Har-Anand Publications, 2008. 